\title{
SACRU Și PROFAN ÎN DENUMIRI ALE SPAȚiULUI public din Ploiești. Străzi și monumente SUBSUMATE UNIVERSULUI EROIC
}

\author{
Gheorghe Calcan \\ Universitatea Petrol-Gaze din Ploiești, România
}

\begin{abstract}
Sacred and profane in naming public places in Ploieşti. Names of streets and monuments pertaining to the heroic universe
\end{abstract}

\begin{abstract}
Our work analyzes the heroic dimension existing in Ploieşti city public space, i.e. in names of streets, public places and monument inscriptions. We have mainly surveyed the impact of the 1989 Romanian revolution on this issue, alongside other related aspects. In Ploieşti there are currently 7 squares, 4 boulevards, 4 roads, 49 entrances, 59 alleys and 781 streets, amounting to a total of 904 "streets". Of the names given to streets, public places, monuments, cemeteries and churches, 63 are circumscribed to the heroic universe. The inscriptions related to these places of public interest provide in their turn an interesting field of investigation.
\end{abstract}

Keywords: Ploiești, street names, monuments.

\section{Introducere}

Problematica atribuirii denumirii străzilor unei localități poate părea omului de rând ca fiind una cotidiană, secundară, adiacentă sau nesemnificativă. Evident, lucrurile nu stau așa. La început, atribuirea denumirilor era explicită: Strada mare, Strada târgului, Strada morii etc.

Mai târziu, și mai ales în cazul localităților mari, lucrurile s-au amplificat. Problematica atribuirii denumirii spațiilor publice a devenit atributul unei politici a decidenților locali.

În ce privește orașul Ploiești, nume de străzi sunt consemnate încă din Evul Mediu. În anul 1882, cunoscutul arhitect Toma N. Socolescu insera în „Planul urbei Ploesci” nomenclatorul străzilor, menționând 236 de denumiri (Onea 2012: 36).

În anul 2002, Jean Paltane publica o lucrare cu caracter eshaustiv (un repertoar) asupra străzilor orașului Ploiești, intitulată: Ghidul străzilor vechi și noi și al cartierelor de locuit din Ploiești, care oferă o bună imagine asupra acestui univers. În prezent (2017), în Ploiești sunt 904 „străzi”, mai exact: 4 bulevarde, 4 șosele, 7 piețe, 49 intrări, 59 alei și 781 străzi (Consiliul local 2015).

Majoritatea copleșitoare a denumirilor se referă la nume de munți, ape, flori, personalități (literare, artistice, istorice, medicale etc.), eroi, bătălii, localități, fenomene naturale (Austrul, Crivăţul, Curcubeul, Azurul) etc. 
Denumirile cu caracter sacru reprezintă numai $2,5 \%$ din totalul numelor de străzi. Dintre acestea, cele mai multe desemnează numele unor mânăstiri (Cernica, Cozia, Putna, Soveja, Văratec etc.), personaje și sărbători religioase creștine (Fecioara, Buna Vestire, Trei Ierarhi), mitropoliți și cărturari, fenomene și elemente religioase.

Specificul petrolier al orașului Ploiești, transpare în denumirea străzilor și instituțiilor sale. În afară de numele unor străzi importante, există și un mic cartier care are aproape în totalitate denumiri de străzi cu semnificaţie petrolieră (v. Avram și Calcan 2013: 241).

$\mathrm{Nu}$ lipsesc nici numele de eroi, locali ori naţionali, atribuite unui număr de 63 de străzi, spații publice ori monumente.

\section{Dinamica schimbării numelor de străzi}

Ca și în alte spații, denumirea străzilor s-a schimbat de-a lungul timpului. Cele mai „spectaculoase” modificări s-au produs după intrarea țării în sfera de control a Uniunii Sovietice, după cel de-al Doilea Război Mondial. Atunci, numeroase denumiri de străzi cu nume ale unor personalități, eroi, bătălii ori regiuni istorice de referință din istoria națională au fost radiate, făcându-se loc altor denumiri. Noile nume s-au subordonat principiilor de a fi favorabile noii orientări politice comuniste a țării, de a fi inofensive intereselor sovietice, de a aduce în prim plan nume rusești ori ale ideologilor comuniști: Balcic > Vasile Roaită > Tribunei (1958); Bucovina > Ion Fonaghi > Sitarului; I. Câmpineanu > Donca Simo > Timiş; Ecaterina Teodoroiu > Lânăriei (1948); General Teutu > Krupskaia (1948); General Praporgescu > Fuiorului (1948); C. A. Rosetti > A. A. Jdanov (1947) > Bobâlna (1964): Piaţa I. G. Duca > I. V. Stalin > Piața 16 Februarie (1962) > Piața Victoriei (1990)

În alte zone ale țării, în afară de „rațiunile” politice generale și de cele „cotidiene” au intervenit și alte criterii în procesul atribuirii numelor de străzi. Exemplificăm prin dinamica acestui fenomen din Transilvania. Revenirea acestei provincii la patria mamă în anul 1918, ori reanexarea părții sale de NV de către Ungaria în perioada anilor 1940 1945 (Felecan 2015: 229-232), ori convieţuirea alături de majoritatea populației românești, a altor comunități etnice au imprimat o „logică” specifică acestui fenomen, „as having the potential to become borders between various ethnic groups and to be associated with a certain ethnic, political or religious identity" (Felecan 2015: 237).

\section{Nume de străzi subsumate universului eroic}

Analiza noastră s-a concentrat, în mod preponderent, pe problematica atribuirii unor denumiri publice în orașul Ploiești, provenite din sfera eroicului.

Un studiu destul de recent, consacrat acestei tematici, remarca faptul că la nivelul anului 2002, în Ploiești existau: 26 de denumiri de străzi care purtau numele unor bătălii celebre în istoria neamului: Călugăreni, Chilia, Cireșoaia, Cosmești, Coșna, Doaga, Gorăslău, Griviței, Mărășești, Nămoloasa, Neajlov, Nicopole, Oituz, Plevna, Podul Înalt, Posada, Rahova, Războieni, Răzoare, Rovine, Smârdan, Soveja, Tabla Buţii, Tatra, Valea Albă, Vidinului; 8 străzi aveau nume de comandanți militari, inclusiv domnitori: 
Candiano Popescu, G-ral. Eremia Grigorescu, G-ral Magheru, G-ral Traian Moșoiu, Mareșal Averescu, Mircea cel Bătrân, Popa Farcaș, Ștefan cel Mare); 25 de străzi cu nume de eroi, inclusiv domnitori eroi: Barbu Catargiu, Brâncoveanu Vodă, Caporal Traian Dumitrescu, Slt. Erou Călin Cătălin, Slt. Erou Constantinoiu Vasile, Slt. Erou Dumitru Boșcovici, Decebal, Ecaterina Teodoroiu, Piața Eroilor, Eroilor, Eroul Necunoscut, G-ral Vasile Milea, Maior Șonțu, Mihai Bravu, Piața Mihai Viteazul, Slt. Erou Moldoveanu Marian, [Baba] Novac, Peneș Curcanul, Cpt. Aviator Popescu Ciocănel, Sergent major Erou Constantinescu Victor, Sergent Erou Mateescu Gheorghe, Sergent Erou Nicolae Arhip, Tudor Vladimirescu, Valter Mărăcineanu, Vlad Țepeș, iar 4 străzi făceau trimitere, prin denumirea lor, la Basarabia și Bucovina de Nord, provincii răpite de Uniunea Sovietică în anul 1940: Codrul Cosminului, Dumbrava Roşie, Constantin Stere, Lăpuşna (Onea 2012: 37).

Comemorarea eroilor locali se află la loc de cinste în orașul Ploiești. Există astăzi străzi, precum: Călin Cătălin ${ }^{1}$, Constantinoiu Vasile ${ }^{2}$ și Moldoveanu Marian ${ }^{3}$, tineri eroi din timpul evenimentelor din 1989.

\section{Monumentele eroilor și înscrisurile lor}

Memoria colectivă a eroilor este adusă în atenția ploieștenilor, la fel ca în alte multe orașe și locuri, prin: cimitire distincte: Cimitirul Eroilor ${ }^{4}$, Cimitirului ostașilor

1 Călin Cătălin s-a născut în Ploiești, la 6 martie 1971. În timpul evenimentelor din Decembrie își satisfăcea stagiul militar la Unitatea militară de la Cernica, de lângă București. A murit la 28 decembrie 1989, la unitatea militară respectivă, fiind împușcat în postul de gardă de către persoane neidentificate. I-a fost conferit titlul de Erou martir (In memoriam 2016: 6).

2 Constantinoiu Vasile, născut în Ploiești, își satisfăcea stagiul militar într-o unitate bucureșteană. A fost împușcat în timpul misiunii de apărare a Palatului Telefoanelor din București. A murit la spital din cauza penetrării plămânilor (In memoriam 2016: 8). În părculețul din curtea liceului a fost cu rapiditate realizat din fier, în atelierul școlii, un mic monument în formă de cruce, care-i însemna datele referențiale alături de un patetic și sincer mesaj: „Constantinoiu N. Vasile, născut la 1.09.1971, decedat la 23.12. 1989. Ai plecat, brav erou, să duci în cer mesajul libertății noastre. Vei fi nemuritor în memoria Neamului” (Calcan 1990: 1-4).

3 Moldoveanu Marian, născut în Ploiești la 15 iulie 1969, era soldat în termen, satisfăcându-și stagiul militar în București. A căzut la datorie, prin împușcări multiple în zona Ministerului Apărării Naționale în chiar ziua prăbușirii regimului comunist, 22 decembrie 1989. A fost înaintat post-mortem la gradul de sublocotenent (In memoriam 2016: 10).

4 Acesta este situat în partea vestică a unui important cimitir local, „Cimitirul Bolovani”, și este particularizat printr-o impunătoare poartă din zidărie, în formă de arc de triumf, cu inscripționarea aferentă și frumos săpată în zid: Cimitirul Eroilor. Dedesubt s-a montat o placă din bronz cu următorul text: „Cimitirul ostașilor români și germani căzuți pe câmpul de luptă în primul și al doilea război mondial. Cimitirul militar Bolovani, Ploiești”. Poarta în arcadă, este ornamentată sobru, în basorelief și cu stilizări specifice acestei tematici: sabie și cunună de frunze de stejar. Partea interioară a acestei porți are inscripția: Onoare Eroilor. Câteva sute de mici monumente în piatră (Popescu 1985: 13; Zorilă 2012: 13), în formă de cruce, aliniate în mai multe rânduri conțin marcat numele ori anonimatul acestor eroi. În acest cimitir își dorm somnul de veci, alături de eroii prahoveni căzuți în primul și cel de al doilea război mondial, militari ai armatelor germană, rusă, maghiară, turcă (Stănescu-Cosma et al. 2013: 31). 
sovietici ${ }^{5}$; monumente: Monumentul Vânătorilor ${ }^{6}$, Monumentul eroilor din 19897; biserici: Catedrală „Sf. Ioan-Botezătorul”, înălțată în perioada interbelică, pentru cinstirea eroilor Primului Război Mondial. Inscripția în marmură amplasată în exterior, în partea dreaptă a intrării face precizarea cuvenită: „Monumentul eroilor prahoveni din Războiul de Întregire a Neamului, 1916-1919”, Biserica Eroilor, numită și Catedrala Eroilor Tineri ${ }^{8}$.

\section{Concluzii}

Investigația noastră conduce la conturarea câtorva concluzii.

Orașul Ploiești are o punctare onorabilă a dimensiunii eroice. Acest fapt este realizat prin modalități diferite: străzi, monumente, biserici etc.

Combinația sacru și profan, constituie o împletire instantanee între monument și mesajul transmis prin inscripționare.

\section{Bibliografie}

Avram, L. și G. Calcan. 2013. Industria petrolieră și reprezentanții acesteia în spațiul public ploieștean. Numele și numirea: instituții și străzi. În Proceedings of the Second International

5 Inscripția de pe monumentul-obelisc, în limbile română și rusă, aflat în acest din urmă cimitir, subsumată retoricii triumfaliste a epocii, este corectă ca fond și mesaj: „Glorie eternă ostașilor sovietici căzuți pentru înfrângerea hitlerismului, pentru pacea și libertatea omenirii”"

6 Înălțat în anul 1897, în prezența regelui Carol I și a veteranilor participanți la acest război (Stănescu-Cosma et al. 2013: 15-26). Complexul monumental (obelisc cu vultur în vârf, statuile a patru soldați cu baionetă, basoreliefuri, obuze, postament și trepte etc.) este amplasat în fața principalei gări a orașului, Gara de Sud.

7 Pe placa de marmură din spatele monumentului sunt gravate cuvintele: „Glorie eternă eroilor prahoveni căzuți în Revoluția din Decembrie 1989” și sunt înscrise numele eroilor prahoveni: Moldoveanu Marian, Călin Cătălin Constantin, Constantinoiu Vasile, Petre Eugen, Ceauș Constantin, Chifor Ioan, Neagu Sebastian Cătălin, Ceapă Nicolae, Preda Ionuț, Hota Ionel, David Constantin, Lambru Gomoescu, Oprescu Adrian, Puiu Sorin, Oncioiu Petre, Ilici Nicoleta, Grigorescu Elena-Ruxandra.

8 Această biserică a fost construită, conform Pisaniei lăcașului, în perioada 1992-2006, şi este dedicată special tinerilor jertfiţi în anul 1989 pentru înlăturarea comunismului. Biserica are două hramuri: Ștefan cel Mare și „Înălțarea Domnului”, dedicat eroilor jertfiți în anul 1989 (Catedrala Eroilor Tineri). Denumirea lăcașului se face printr-un vizibil panou/placardă, susținut de doi piloni metalici înalți, cu inscripția: Biserica Eroilor „Înălțarea Domnului” și” Sfântul Ștefan cel Mare". Panoul inscripționat mai are decorat simbolic două cruci și Tricolorul.

Obeliscul, de formă pătrată, placat în marmură, are în vârf trei cruci din piatră, frumos așezate asimetric și în trepte. Lângă monument un catarg arborează drapelul național. Monumentul gravează pe trei laturi ale sale numele celor 51 de eroi din Prahova, din anul 1989. Monumentul este realizat de cunoscutul sculptor local Nicolae Kruch.

Placa omagială din interiorul bisericii, este amplasată simetric în raport cu Pisania lăcașului, pe peretele vestic, imediat după intrare. Ea are săpat în marmură, în ordine alfabetică, numele celor 51 de eroi prahoveni. Pe frontispiciul acesteia, după un scurt citat al lui Nicolae Iorga, este gravat textul: „Glorie ostașilor prahoveni ai lui Decembrie 1989”. 
Conference on Onomastics "Name and Naming” Onomastics in Contemporary Public Space, Baia Mare, May 9-11, 2013, O. Felecan (ed.), 980-990. Cluj-Napoca: Mega, Argonaut.

Calcan, G. 1990. El s-a jertfit pentru noi. Prahova Liberă II (286-287): 1-4.

Calcan, G. 2013. Nume de străzi ale localităților din Comuna Săgeata, județul Buzău. În Proceedings of the Second International Conference on Onomastics "Name and Naming" Onomastics in Contemporary Public Space, Baia Mare, May 9-11, 2013, O. Felecan (ed), 254262. Cluj-Napoca: Mega, Argonaut.

Calcan, G. 2016. Petrolul românesc - un brend național și local. În Administrarea afacerilor în industria de petrol și gaze, Studii de caz și seminarii științifice, L. Dumitrașcu (coord.), 225-250. Ploiești: Universitatea Petrol-Gaze.

Consiliul Local al Municipiului Ploiești, Hotărârea nr. 84 privind actualizarea nomenclatorului stradal al municipiului Ploiești, 26 februarie 2015.

Felecan, O. 2015. Borders and Ethnic Identities Reflected in Street Names from Transylvanian Localities. Transylvanian Review XXIV (Supplement No. 1): 229 -244.

https://elenushu.wordpress.com/2011/12/10/catedrala-eroilor-tineri-inaltarea-domnului-din-ploiesti/ (accesat în 4 iulie 2017).

Onea, O. 2012. O reparaţie - străzi cu nume de eroi. Prahova eroică 3: 35-37.

Paltane, J. 2002. Ghidul străzilor vechi și noi și al cartierelor de locuit din Ploiești. Ploiești: ALT Vision.

Popescu, P. D. 1985. Ghid de oraș, Ploiești. București: Sport-Turism.

Stănescu, E., M. Cosma, G. Preda și I. Stănescu. 2013. Jertfele prahovenilor. Monumentele recunoștinței. Ploiești: Karta Graphic.

Zorilă, P. 2012. Monumente ale eroilor ploieșteni din primul război mondial. Prahova eroică 3 : 13-15. 